\title{
ADVANCED BREAST CANCER IN NIGERIA: A SINGLE CENTRE EXPERIENCE
}

\section{Wichendu P.N. ${ }^{2}$ and Dodiyi-Manuel A. ${ }^{2}$}

\author{
${ }^{1}$ Department Of Surgery, University of Port Harcourt Teaching Hospital, Choba, Port \\ Harcourt \\ E-mail: promise.wichendu@ uniport.edu.ng \\ ${ }^{2}$ Department Of Surgery, University of Port Harcourt Teaching Hospital, Choba, Port \\ Harcourt \\ E-mail: dodman_05@yahoo.com
}

Cite this article:

Wichendu P.N., DodiyiManuel A. (2021), Advanced Breast Cancer in Nigeria: A Single Centre Experience. African Journal of Biology and Medical Research 4(2), 51-56. DOI: 10.52589/AJBMRT1CPAENI.

\section{Manuscript History}

Received: 19 April 2021

Accepted: 11 May 2021

Published: 17 May 2021

Copyright $\odot 2020$ The Author(s). This is an Open Access article distributed under the terms of Creative Commons AttributionNonCommercial-NoDerivatives 4.0 International (CC BY-NC-ND 4.0 ), which permits anyone to share, use, reproduce and redistribute in any medium, provided the original author and source are credited.
ABSTRACT: Background: Breast cancer is the most common cancer globally and in Nigeria, it constitutes about $12 \%$ of all new cancers and $25 \%$ of all cancers in women. In Nigeria, the majority of patients present with late disease and globally, advanced breast cancer is associated with a low survival rate among patients. This study seeks to review the presentation of advanced breast cancer as seen in the University of Port Harcourt Teaching Hospital, Southern Nigeria. Patients and Methods: This is a 5-year retrospective study conducted at the University of Port Harcourt Teaching Hospital. Records of patients that presented to the hospital within the study period with histologically proven breast cancer (stages 3 and 4) were retrieved, and relevant data extracted and analysed using SPSS version 22. Results: There were 47 patients with advanced breast cancer and they were all females. Their ages ranged from 25 to 72 years with a mean of $43.9 \pm 4.7$ and peak age of 31-50 years. Majority of the patients (72.3\%) had stage 3 disease while 13 $(27.7 \%)$ of them had stage 4. The lung was the commonest metastatic site and this was seen in 7 (14.9\%) patients, followed by the liver in 1 (2.1\%). Conclusion: Advanced breast cancer remains a dreaded disease that reduces patients' quality of life significantly and may also be rapidly fatal. Community-based efforts in collaboration with Non-Governmental Organizations (NGOs) targeted at information dissemination to the public, and offering breast cancer screening and subsidized cancer treatment are essential to reduce the mortality associated with this deadly disease.

KEYWORDS: Presentation, advanced breast cancer, University of Port Harcourt Teaching Hospital. 


\section{INTRODUCTION}

Female breast cancer has now surpassed lung cancer as the leading cause of global cancer incidence in 2020, with an estimated 2.3 million new cases, representing $11.7 \%$ of all cancer cases, and ranking fifth as the leading cause of cancer mortality worldwide ${ }^{\mathbf{1}, 2}$. In Nigeria, it constitutes about $12 \%$ of all new cancers and $25 \%$ of all cancers in women ${ }^{1}$.

Incidence rates in sub-Saharan Africa have also been on the increase ${ }^{2}$. In Zaria, every 1 in 5 cases of breast lump at the Ahmadu Bello University Teaching Hospital is malignant ${ }^{3}$. It has been documented that the majority of patients in Nigeria present late with advanced disease $^{\mathbf{4 , 5}}$. Low survival rates in sub-Saharan Africa are largely attributable to this late-stage presentation. According to a report summarizing 83 studies across 17 sub-Saharan African countries, $77 \%$ of all staged cases were stage III/IV at diagnosis ${ }^{6}$. The reasons for the late presentation include low level of literacy, cultural and religious beliefs, ignorance, high poverty rate and absence of organized, population-based mammography screening programs amongst others ${ }^{7}$. A recent study conducted in 5 sub-Saharan African countries estimated that $28 \%$ to $37 \%$ of breast cancer deaths in these countries could be prevented through earlier diagnosis of symptomatic disease and adequate treatment, with a fairly equal contribution of each $^{8}$. All over the world, advanced breast cancer is associated with a low survival rate among patients $^{9,10}$. In such patients, the aim of treatment is palliative with improvement in the quality of life, symptom control and prolonging survival as the main objectives ${ }^{11}$. This study reviews the presentation of advanced breast cancer in the University of Port Harcourt Teaching Hospital.

\section{PATIENTS AND METHODS}

This is a 5-year retrospective study conducted at the University of Port Harcourt Teaching Hospital between 1st January, 2013 and 31st December, 2017. Records of patients that presented to the Hospital within the study period with histologically confirmed breast cancer were retrieved. Relevant data which included age, age at menarche, menopausal status, parity, breastfeeding history, family history of breast cancer, stage of disease, presenting symptoms and metastatic sites were extracted and analyzed using Statistical Package for Social Sciences, Version 21.

\section{RESULTS}

There were 47 patients with advanced breast cancer within the study period and they were all females. Their ages ranged from 25 to 72 with a mean of $43.9 \pm 4.7$ and the peak age incidence was $31-50$ age range (See table 1$)$. Only $1(2.1 \%)$ had a family history of breast cancer (See table 1). Their ages at menarche ranged from 11 to 18 years with a mean of $14.1 \pm 1.2$. Twentyseven $(57.4 \%)$ patients were premenopausal while $20(42.6 \%)$ of them postmenopausal (See table 1). Only $7(14.9 \%)$ of the patients were nulliparous. The others are as shown on table 1. Forty two (89.4\%) patients breastfed their children for an average of 1 year. The right breast was the most commonly involved site and this was seen in 25 patients (53.2\%). In 19 (40.4\%) patients, the cancer was on the left breast and it was bilateral in $3(6.4 \%)$ (See table 1). Majority of the patients $(72.3 \%)$ had stage 3 disease while $13(27.7 \%)$ of them had stage 4. 
African Journal of Biology and Medical Research

ISSN: $2689-534 \mathrm{X}$

Volume 4, Issue 2, 2021 (pp. 51-56)

www.abjournals.org

Painless breast lump was the commonest presenting symptom and this was seen in 38 (80.6\%). Other presenting symptoms are as seen on table 2 . The lung was the commonest metastatic site and this was seen in $7(14.9 \%)$ patients, followed by the liver in $1(2.1 \%)$. The other metastatic sites are as shown on table 3 .

Table 1: Patient and Disease Characteristics of Breast Cancer Patients

\begin{tabular}{|l|l|}
\hline Variable (n-47) & No of patients (\%) \\
\hline Age range of patients & $6(12.8)$ \\
$14-20$ & $14(29.8)$ \\
$21-30$ & $14(29.8)$ \\
$31-40$ & $16(35.7)$ \\
$41-50$ & $1(2.1)$ \\
$51-60$ & $2(4.3)$ \\
$61-70$ & \\
$71-80$ & \\
\hline Age at menarche & $3(6.4)$ \\
$<12$ & $24(51.1)$ \\
\hline /=12 & \\
\hline Menopausal status & $27(57.4)$ \\
Premenopausal & $20(42.6)$ \\
Post-menopausal & \\
\hline Parity & $7(14.9)$ \\
Nulliparous & $21(44.7)$ \\
$1-4$ & $19(40.4)$ \\
$>/=5$ & \\
\hline Breast feeding & $42(89.4)$ \\
Yes & $5(10.6)$ \\
No & \\
\hline Variables (n-47) & No of patients (\%) \\
\hline Stage & $34(72.3)$ \\
3 & $13(27.7)$ \\
\hline 4 & $1(2.1)$ \\
\hline Family history & $46(97.9)$ \\
\hline Yes & \\
No & \\
\hline
\end{tabular}


African Journal of Biology and Medical Research

ISSN: $2689-534 \mathrm{X}$

Volume 4, Issue 2, 2021 (pp. 51-56)

www.abjournals.org

Table 2: Presenting symptoms

\begin{tabular}{|l|l|}
\hline Symptoms & No of patients (\%) \\
\hline Breast lump & \\
Painless & $38(80.9)$ \\
Painful & $4(8.5)$ \\
\hline Fungating mass & $7(14.9)$ \\
\hline Serous nipple discharge & $1(2.1)$ \\
\hline Bloody nipple discharge & $1(2.1)$ \\
\hline Dyspnea & $2(4.3)$ \\
\hline Cough & $1(2.1)$ \\
\hline Chest pain & $1(2.1)$ \\
\hline Pleural effusion & $1(2.1)$ \\
\hline
\end{tabular}

Table 3: Metastatic sites

\begin{tabular}{|l|l|}
\hline Site & No of patients (\%) \\
\hline Lungs & $7(14.9)$ \\
\hline Liver & $3(6.4)$ \\
\hline Peritoneum & $1(2.1)$ \\
\hline Bone & $1(2.1)$ \\
\hline Brain & $1(2.1)$ \\
\hline
\end{tabular}

\section{DISCUSSION}

Advanced breast cancer confers a huge burden on the patient, doctor and the healthcare system. Developed countries place emphasis on screening and this has led to early detection over the past 3 to 4 decades $^{\mathbf{1 2}}$. Conversely, in some developing countries like Nigeria, in addition to the limitation of resources, routine screening for breast cancer is not a common practice and many patients still present late. The mean age of 43.89 and peak age incidence of 31-50 years are similar to previous reports from Nigeria ${ }^{\mathbf{1 2}}$. Generally, it has been reported that breast cancer presents much earlier in Nigeria and most other African countries than it does in the Western population ${ }^{\mathbf{1 3 , 1 4}}$. Most of the patients $(80.9 \%)$ had painless breast lump as the first symptom. In agreement with previous findings, the painless nature of the lump (as a result of being ignored) might have contributed to the late presentation with worsening prognosis ${ }^{\mathbf{1 5}, 16}$. It has been documented that about $15-20 \%$ of all breast cancer cases are familial ${ }^{17}$. In our study, only $2.1 \%$ of the patients reported a family history of breast cancer. The rest either did not have or were unaware of a family history. It is possible that absence of family history in the patients might have also contributed to the delay in presentation. This is because relevant family history is expected to trigger more rapid evaluation and a self-detected breast complaint ${ }^{16,18}$. The bone has been reported to be the commonest metastatic site following advanced breast cancer ${ }^{19}$. Patanaphen et al. reported the bone as the commonest site in $51 \%$ of their patients followed by the lungs in $17 \% .{ }^{20}$ Schneider et al. also reported the bone as the commonest site of spread and this was found in $14.7 \%$ of patients followed by the liver in $5.7 \% .^{21}$. In our study, the lungs were the commonest site and this was found in $14.9 \%$ of our patients followed by the liver in 
$6.4 \%$. The bone was involved in only $2.1 \%$ of cases. This variation observed in this study might be due to the fact that there is no facility for skeletal scintigraphy in our centre. This imaging modality might have detected more cases of bone metastasis because it is more sensitive than skeletal x-ray which requires a loss of $30-75 \%$ normal bone mineral content before the osteolytic lesions become apparent ${ }^{22,23}$.

\section{CONCLUSION}

Advanced breast cancer remains a dreaded disease that reduces patients' life expectancy and quality of life significantly. Community-based efforts in collaboration with non-Governmental organizations targeted at information dissemination to the public, and offering breast cancer screening and subsidized cancer treatment are essential to reduce the mortality associated with this disease.

\section{REFERENCES}

[1] Desantis C, Ma J, Bryan L, Jermal A. Breast cancer statistics, 2013. CA Cancer J Clin 2014; 64: 52-62.

[2] Global Cancer Statistics 2020

[3] Yusufu LM, Odigie VI, Mohammed A. Breast masses in Zaria. Am Afr Med 2003; 2: 13-16.

[4] Ezeome ER. Delays in presentation and treatment of breast cancer in Enugu, Nigeria. Niger J Clin Pract 2010; 13: 311-316.

[5] Ajikegbe AT. Fear of mastectomy: The most common factor responsible for late presentation of carcinoma of the breast in Nigeria. Clin Oncol (R Coll Radiol) 1991; 3: 78-80.

[6] Jedy-Agba E, McCormack V, Adebamowo C, Dos-Santos-Silva I. Stage at diagnosis of breast cancer in sub-Saharan Africa: a systematic review and meta-analysis. Lancet Glob Health. 2016;4:e923-e935.

[7] Wang F, McLafferty S, Escamilla V, Luo L. Late-stage breast cancer diagnosis and health care access in Illinois. Prof Geogr 2008; 60: 54-69.

[8] . McCormack V, McKenzie F, Foerster M, et al. Breast cancer survival and survival gap apportionment in sub-Saharan Africa (ABC-DO): a prospective cohort study. Lancet Glob Health. 2020;8:e1203-e1212.

[9] Gennari A, Conte P, Rosso R, Orlandini C, Bruzzi P. Survival of metastatic breast carcinoma patients over a 20-year period. Cancer 2005; 104: 1742-1750.

[10] Falkson G, Holcroft C, Gelman R, Tormey DC, Wolter JM, Cummings FJ. Ten-year follow -up study of premenopausal women with metastatic breast cancer: An Eastern Cooperative Oncology Group Study. J Clin Oncol. 1995; 13: 1453-1458.

[11] Chung CT, Carlson RW. Goals and objectives in the management of metastatic breast cancer. The Oncologist. 2003; 8: 514-520.

[12] Blanks RG, Moss SM, McGahan CE, Quim MJ, Babb PJ. Effects of NHS breast screening programme on mortality from breast cancer in England and Wales 1990-8: comparison of observed with predicted mortality. BMJ. 2000; 321: 665-669. 
[13] Adisa AO, Arowolo OA, Akinkualie AA, Titiloye NA, Alatise OI, Lawal OO, et al. Metastatic breast cancer in a Nigerian tertiary hospital. Afr Health Sci 2011; 11: 279284.

[14] Ikeri NZ, Oguntunde OA, Igbokwe U, Abdulkareem FB, Banjo AA. Breast cancer in a Lagos facility: Implications for the institution of a cancer screening programme. Pathobiology 2018; 85: 254-260.

[15] Marmot MG, Altman DG, Cameron DA, Dewar JA, Thompson SG, Wilcox M. The benefits and harms of breast cancer screening: an independent review. Br Cancer 2013; 108: 2205-2240.

[16] Ramirez AJ, Westcombe AM, Burgess CC, Sutton S, Littlejohns P, Richards MA, et al. Factors predicting delayed presentation of symptomatic breast cancer: A systematic review. Lancet 1999; 353: 1127-1131.

[17] Awofeso O, Roberts AA, Salako O, Balogun L, Okediji P. Prevalence and pattern of late-stage presentation in women with breast and cervical cancers in Lagos University Teaching Hospital, Nigeria. Nig Med J 2018; 59: 74-79.

[18] Colditz GA, Willet WC, Hunter DJ, Stampfer MJ, Manson JE, Hennekens CH, et al. Family history, age and risk of breast cancer. Prospective data from Nurses health study. JAMA 1993; 270: 338-343.

[19] Eggen T, Anus M, Moe B, Straume B, Orbo A. Prognosis of early cervical cancer (FIGO stager IA2, IB and IIA) in Northern Norway predicted by malignancy grading score and objective morphometric image analysis. Int J Gynecol Pathol 2007; 26: 447456.

[20] Ibrahim H, Umar AK. Pattern of patients' presentation with metastatic breast cancer for palliative external beam radiotherapy in the University College Hospital, Ibadan. Ann Trop Pathol2018; 9: 131-134.

[21] Patanaphan V, Salazar OM, Risco R. Breast cancer: metastatic cancer patients and their prognosis. South Med J 1988; 81: 1109-1112.

[22] Schneider G, Fehr MK, Steiner RA, Hagen D, Haller U, Fink D, et al. Frequency and distribution pattern of distal metastasis in breast cancer patients at the time of primary presentation. Arch Gynecol Obstet 2003; 269: 9-12.

[23] Galasko CS. Skeletal metastases and mammary cancer. Ann R Coll Surg Eng 1972; 50: 3-28.

[24] Krasnow AZ, Hellman RS, Timins ME, Collier BD, Anderson T, Isitman AT. Diagnostic bone scanning in oncology. Semin Nucl Med 1997; 27: 107-141. 